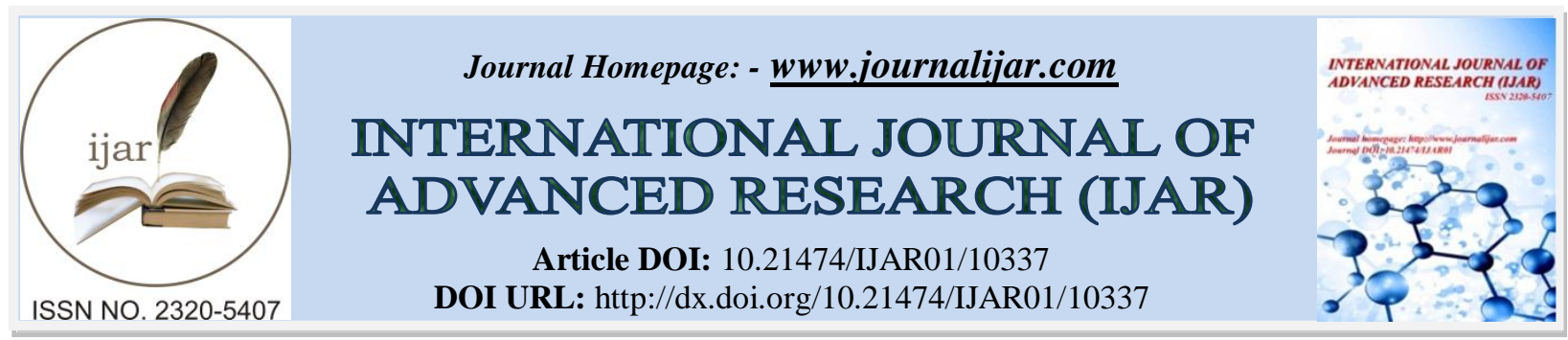

RESEARCH ARTICLE

\title{
CYTOKERATIN-POSITIVE SUBSEROSAL MYOFIBROBLASTS IN PERFORATED ACUTE APPENDICITIS : A CASE REPORT AND LITERATURE REVIEW
}

\author{
Dr. Achraf Miry MD. ${ }^{1}$, Dr. Elmehdi Tiabi MD. ${ }^{1}$, Pr. Amal Bennani MD. ${ }^{1}$, Dr. Fatima-Zahra Rahou MD. ${ }^{2}$ \\ and Pr. Mohamed Bouziane MD. ${ }^{2}$. \\ 1. Pathology Department, Mohamed VI University Hospital, Oujda, Morocco. \\ 2. General Surgery, Mohamed VI University Hospital, Oujda, Morocco.
}

\section{Manuscript Info}

\section{Manuscript History}

Received: 27 November 2019

Final Accepted: 30 December 2019

Published: January 2020

Key words:-

Appendicitis,

Myofibroblasts

\section{Abstract}

In the normal appendix, myofibroblasts are found as normal cells in the mucosal pericryptal region. These cells play an important role in organogenesis and wound healing. We report the case of a 7 years old boy, who was admitted for an acute perforated appendicitis. An appendicectomy was performed with revelation of an appendiceal wall perforation. Histological examination of the appendicectomy specimen is performed. Samples taken from the area of perforation showed large number of moderately atypical spindle or stellate-shaped cells with large hyperchromatic nuclei with some observed multinucleations. Cytoplasm is often elongated and eosinophilic. Some rare mitotic figures were present. These cells express pancytokeratin and SMA, with no expression of $\mathrm{H}$-caldesmon. In case of perforated acute appendicitis, cytokeratin- and SMA-positive myofibroblasts are observed in the subserosa. There are several theories trying to explain the origin of subserosal myofibroblastes. One theory postulates that these cells could originate from CD34 positive stromal cells, a second one links these cells to mesothelial cells and recently, it is believed that submesothelial cell could be the origin.

Copy Right, IJAR, 2020,. All rights reserved.

\section{Introduction:-}

Myofibroblasts are found as normal cells in many organs, including the digestive tract, where they predominate in the pericryptal region. [1-8] These cells play an important role in organogenesis and wound healing [7]

Although myofibroblasts could be present in the serosa in cases of ulcer and neoplastic disease, they are generally absent in this location. [1,2,9]

There are several theories trying to explain the origin of subserosal myofibroblastes. One theory postulates that these cells could originate from CD34 positive stromal cells, a second one links these cells to mesothelial cells and recently, it is believed that submesothelial cell could be the origin as in cases of perforated gastric and duodenal ulcers. $[4,6,10,11]$

This later theory could be an explanation for observed myofibroblasts in the appendix subserosa in cases of appendicitis with perforation, as it was already demonstrated in a recent study [12,13] 
In this work, we report the case of an acute perforated appendicitis in which cytokeratin positive myofibroblastes were observed in the subserosa. Our work contains a literature review and aims to prevent over interpreting the presence of cytokeratin myofibroblasts in the subserosa in perforated appendicitis as a neoplastic disease.

\section{Case report:-}

We report the case of a 7 years old boy, who was admitted to the emergency room for an appendicular syndrome made of 12 hours history of right iliac fossa pain, fever and vomiting. Explorations have revealed a thickened appendiceal wall with suspicion of perforation. White blood cells count was at $16.10^{9} \mathrm{WBC} / \mathrm{l}$. No other abnormal clinical or biological findings were observed.

A diagnosis of acute appendicitis with suspicion of perforation was made. An appendicectomy was performed with revelation of an appendiceal wall perforation.

Gross examination revealed a $7 \times 1 \mathrm{~cm}$ appendix specimen with a $0,4 \mathrm{~cm}$ perforation on its tip. The serosa was congested and the mucosa showed ulceration and hyperemia.

The histological examination showed a dense neutrophilic infiltrates of the wall of the appendix. Samples taken from the area of perforation showed a connective tissue that was infiltrated by a large number of moderately atypical spindle or stellate-shaped cells with large hyperchromatic nuclei with some observed multinucleations. Cytoplasm is often elongated and eosinophilic. Some rare mitotic figures were present. (Figure 1 and 2)

An immunohistochemical study has revealed that the observed atypical cells mutually express pancytokeratin and SMA, with no expression of $\mathrm{H}$-caldesmon. (Figure 3)

The use of anti-CD34 antibodies has revealed disappearance of CD34 positive stromal cells in the subserosa.

\section{Discussion: -}

Myofibroblasts, as in other parts of the digestive tract, are normally found only in the pericryptal region of the appendiceal mucosa [13]

This fact has been already proven in the stomach, duodenum, colon and recently in the appendix. [7, 8, 13, 14]

The origin of normal pericryptal myofibroblasts is not yet fully elucidated. On one hand, in a study made by Brittan et al., the myofibroblasts, normally present in the pericryptal region of the human small intestine and colon could originate from the bone marrow. [15]

On the other hand, these normal myofibroblasts could originate from the adventitial cells of the submucosa blood vessels, as proposed in a study by Powell et al. [7,8]

Cytokeratin-positive myofibroblasts in the subserosal layer were first observed and described in gastric and duodenal ulcers by Pitt and Haboubi [9]

As in cases of gastric and duodenal ulcers, Cyokeratin positive myofibroblasts are observed in the subserosa in and around the area of perforation in cases of acute appendicitis with perforation. [4, 6, 13]

In a recent study by T. Hamauzu et al., it was observed that cases of acute appendicitis with perforation were characterized by an abundant number of Pancytokeratin-positive myofibroblasts and complete absence of CD34positive stromal cells in the subserosa of the area of perforation. [13]

Many hypotheses trying to explain the origin of these myofibroblasts exist. The more recent one postulate that they could originate from the CD34-positive stromal that are normally present in the appendiceal subserosa and disappear in many lesions of the appendix. $[4,6,10]$

In the study conducted by Hamauzu et al., using double staining with SMA and Cytokeratin, it was postulated that since subserosal myofibroblasts co-express SMA and Cytokeratin, the most possible origin is therefore the submesothelial or mesotheliale cells. [13] 
One of the reasons why to consider submesothelial cell as a potential origin for cytokeratin-positive myofibroblasts, is the fact that submesothelial cells are regarded as multipotential mesenchymal cells since they do express low molecular weight cytokeratin as well as vimentin while proliferating in case of mesothelial injuries. [16]

The cellular transformation is a well-known phenomenon that occurs in the aim of recompensing tissue injury, as it was also postulated in a study by Amari et al. where it was shown that the fibroblast is the origin of regenerated mesothelial cells that cover the surface of the body cavities. [17]

However, a more recent study showed that mutlipotent subserosal cells, rather than submesothelial cell could be the origin -based on immunohistochemical studies- of activated cytokeratin-positive myofibroblasts. [13]

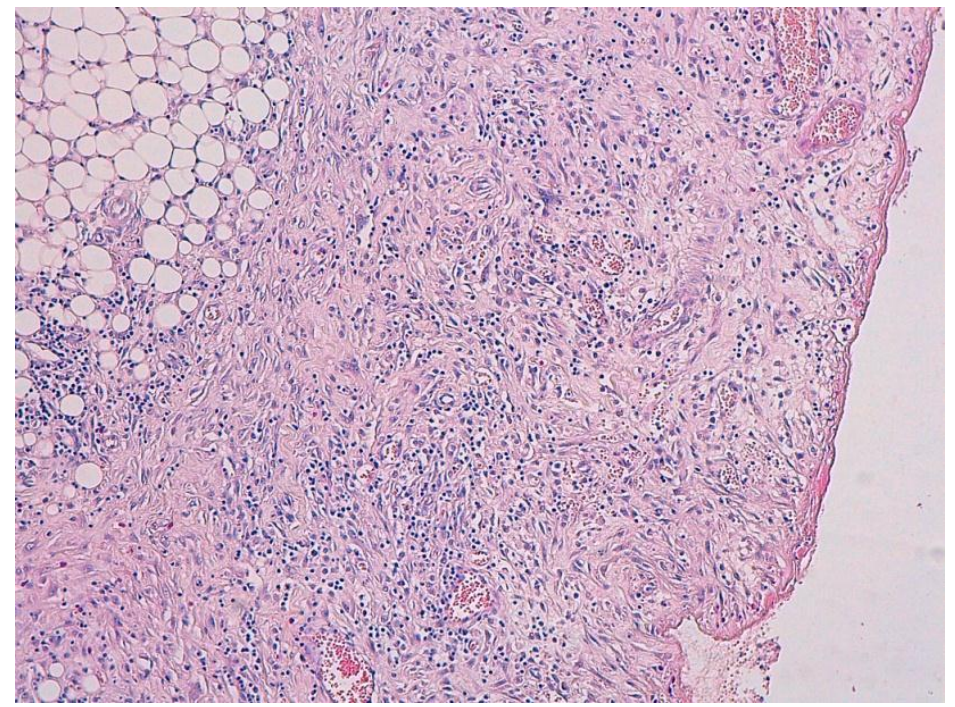

Figure 1:- Microphotography showing infiltration of the subserosa by spindle and stellate-shaped cells. (HE; 200X).

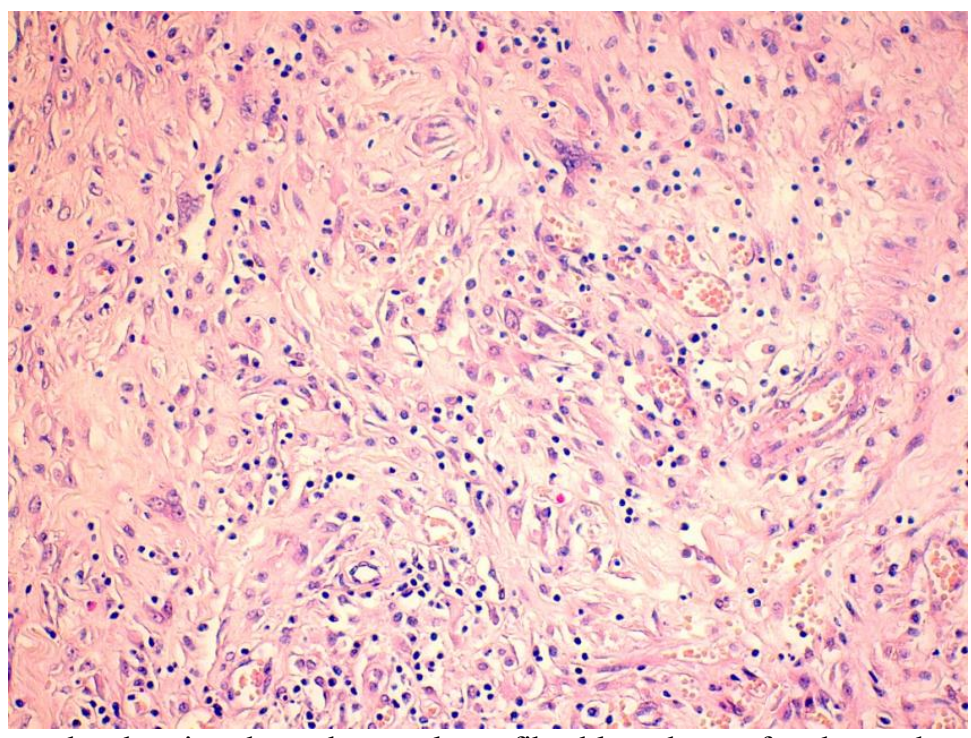

Figure 2:- Microphotography showing that subserosal myofibroblasts have often hyperchromatic nuclei with some observed multinucleations. Cytoplasm is often elongated and eosinophilic. (HE; 400X). 


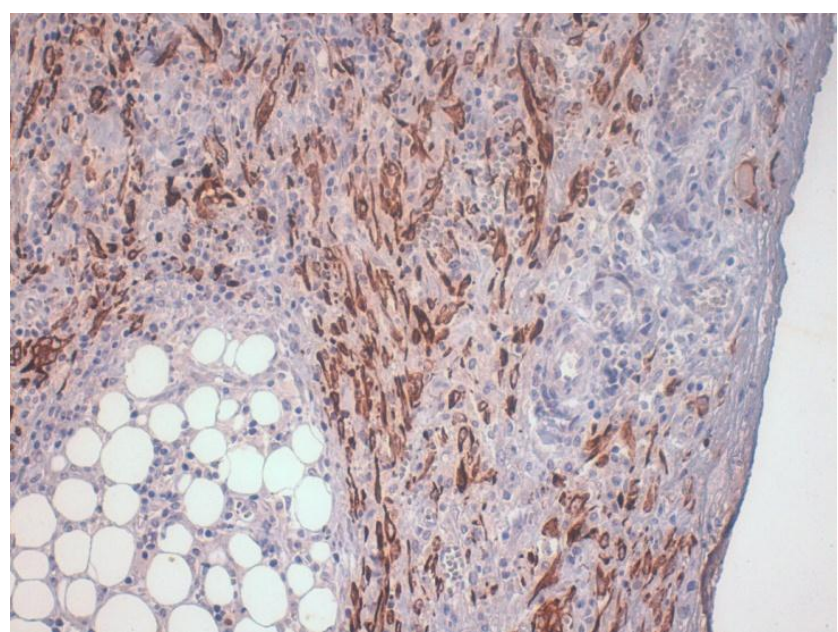

Figure 3:- Microphotography showing expression of pancytokeratin by subserosal myofibroblasts.

\section{Conclusion:-}

The theories discussing subserosal cytokeratin-positive myofibroblasts contribute to a better understanding of the origin and exact role of these cells appearing around the perforation zone of appendicitis, however more investigations are needed.

\section{Acknowledgements:-}

None. No funding to declare.

\section{Conflict of Interest:-}

All authors have no conflict of interest to report.

\section{References:-}

1. Nakayama H, Enzan H, Miyazaki E, Kuroda N, Naruse K, Kiyoku H, Hiroi M (2000) Myofibroblasts at the tumor border of invasive gastric carcinomas: with special reference to histological type and tumor depth. Oncol Rep 7:1011-1015

2. Nakayama H, Enzan H, Miyazaki E, Naruse K, Kiyoku H, Hiroi M (1998) The role of myofibroblasts at the tumor border of invasive colorectal adenocarcinomas. Jpn J Clin Oncol 28:615-620

3. Kuroda N, Toi M, Nakayama H, Miyazaki E, Yamamoto M, Hayashi Y, Hiroi M, Enzan H (2004) The distribution and role of myofibroblasts and CD34-positive stromal cells in normal pancreas and various pancreatic lesions. Histol Histopathol 19:59-67

4. Barth PJ, Ramaswamy A, Moll R (2002) CD34 $\square \square$ fibrocytes in normal cervical stroma, cervical intraepithelial neoplasia III, and invasive squamous cell carcinoma of the cervix uteri. Virchows Arch 441:564-568

5. Kuroda N, Nakayama H, Miyazaki E, Hayashi Y, Toi M, Hiroi M, Enzan H (2004) Distribution and role of CD34-positive stromal cells and myofibroblasts in human normal testicular stroma. Histol Histopathol 19:743751

6. Kuroda N, Miyazaki E, Hayashi Y, Toi M, Hiroi M, Enzan H (2004) The disappearance of CD34-positive and alpha-smooth muscle actin-positive stromal cells associated with human intra-uterine and tubal pregnancies. Histol Histopathol 19:707-713

7. Powell DW, Mifflin RC, Valentich JD, Crowe SE, Saada JI, West AB (1999) Myofibroblasts. II. Intestinal subepithelial myofibroblasts. Am J Physiol 277 (Cell Physiol 46):C183-C201

8. Powell DW, Mifflin RC, Valentich JD, Crowe SE, Saada JI, West AB (1999) Myofibroblast. I. Paracrine cells important in health and disease. Am J Physiol 277 (Cell Physiol 46):C1-C19

9. Pitt MA, Haboubi NY (1995) Serosal reaction in chronic gastric ulcers: an immunohistochemical and ultrastructural study. J Clin Pathol 48:226-228

10. Adegboyega PA, Mifflin RC, DiMari JF, Saada JI, Powell DW (2002) Immunohistochemical study of myofibroblasts in normal colonic mucosa, hyperplastic polyps, and adenomatous colorectal polyps. Arch Pathol 
Lab Med 126:829-836

11. Jimenez-Heffernan JA, Aguilera A, Aroeira LS, Lara-Pezzi E, Bajo MA, del Peso G, Ramirez M, Gamallo C, Sanchez-Tomero JA, Alvarez V, Lopez-Cabrera M, Selgas R (2004) Immunohis- tochemical characterization of fibroblast subpopulations in normal peritoneal tissue and in peritoneal dialysis-induced fibrosis. Virchows Arch 444:247-256

12. Chauhan H, Abraham A, Phillips JRA, Pringle JH, Walker RA, Jones JL (2003) There is more than one kind of myofibroblasts: analysis of CD34 expression in benign, in situ, and invasive breast lesions. J Clin Pathol 56:271-276

13. Hamauzu, T., Kuroda, N., Guo, L., Miyazaki, E., Hayashi, Y., Toi, M., \& Enzan, H. (2006). CAM5. 2-positive subserosal myofibroblasts in appendicitis. Medical molecular morphology, 39(4), 209-213.

14. Adegboyega PA, Mifflin RC, DiMari JF, Saada JI, Powell DW (2002) Immunohistochemical study of myofibroblasts in normal colonic mucosa, hyperplastic polyps, and adenomatous colorectal polyps. Arch Pathol Lab Med 126:829-836

15. Brittan M, Hunt T, Jeffery R, Poulsom R, Forbes SJ, Hodivala- Dilke K, Goldman J, Alison MR, Wright NA (2002) Bone marrow derivation of pericryptal myofibroblasts in the mouse and human small intestine and colon. Gut 50:752-757

16. Bolen JW, Hammar SP, McNutt MA (1986) Reactive and neo- plastic serosal tissue. A light-microscopic, ultrastructural, and immunocytological study. Am J Surg Pathol 10:34-47

17. Amari M, Taguchi K, Iwahara M, Naoe S, Takahashi K (2004) Immunohistochemical and ultrastructural studies of the effects of predonisolone on transformation of fibroblasts to regenerated mesothelial cells. Med Electron Microsc 37:242-251. 